great loss of prosperity sustained by the State by its neglect of sanitary science. A different course "would have more than doubled the population during the past ten years." The profession has urged this subject repeatedly, but has not met with a favorable response from the state government.

\title{
THE NATIONAL BOARD OF HEALTH.
}

Mr. Editor, - I have been prevented, by an accident that happened to me in February last, from attending any of the meetings of the National Board of Health until a few weeks ago.

The insinuations and severe or contemptuous criticisms occasionally indulged in by the Northern daily press against the operations and members of the board I thought were undeserved, but my want of knowledge of the "inward workings" of the board at Washington has checked my desire to defend it or its members. Last month $I$ was able to attend one of its meetings. It continued three days, and I have rarely seen so much hard work done in the same length of time. From early in the forenoon till evening the board was in session. Telegrams were constantly being received and sent from and to various parts of the country relative to many matters; orders here and there were being dictated to clerks, some of whom "worked from fourteen to sixteen hours daily." Certainly, there was no lack of energy displayed. And, for one, I was fairly tired out by my three days of work, even as a simple member. The number and variety of new questions constantly coming up kept our minds always alert.

Any one who has paid attention to the progress of the sanitary education of our people must have been convinced that a national board of health was a foregone conclusion, when that education should be sufficiently advanced. Unfortunately, as I deem it for the board's reputation and efficiency, it was prematurely hurried into life by the panic caused in the public mind at the prospect of a repetition, this year, of the horrors of the last year's epidemic in our Southern States. Congress influenced by that panic hastily passed the bill creating the board. The old discussion of national and state rights hampered the members of Congress, and, as usual, when any large sums of money are likely to be expended, some unlooked-for things were done. Immense powers were, apparently, given to the board to regulate the transactions of one part of the country with another, and more than half a million of dollars was put, apparently, at its disposal, to enable it to perform its duties.

I use this qualifying expression "apparently" with the intention of being strictly true in the use of words. The attorney-general of the United States decided, after due consideration of the terms of the bill, that the board's rules and regulations would be all null and void, unless adopted by the local sanitary authorities! The board therefore is obliged virtually to say, "Here are rules which we deem essential - they are the least that ought to be required. You may have others, but they must include, in principle, those proposed by us, or you shall not receive a dime of the money granted us by Congress." Of course our rules have been readily adopted by all those places 
threatened with fever. They have been simply ignored, I suspect, by others. Still further, not a dollar can be spent without the close supervision of the comptroller of the treasury. The most minute items of each account are required, and all may be rejected by the said comptroller of the treasury. For example, one of our members, after passing some time at Washington, had upon his bill a small item for washing. It was rejected! You will see from the above statement that our authority for making rules for the country is mightily cramped, and our power over the moneys granted by Congress is watched with Argus eyes by the Washington officials. In one contingency, however, the board has very great and summary power, if the president of the United States consents. It has already occurred and it may hereafter happen that for some reason, either carelessness or willfulness or inability under the laws of a State, a certain community may find itself unprotected from the incursion of contagious or infectious diseases, and then this power can be iuvoked. For example, Philadelphia and Baltimore and other cities near these two have been heretofore unable to defend themselves from " runn ers" from these cities, who, after boarding vessels infected with the pestilential diseases, have brought back the same to these various places. Neither Pennsylvania, Delaware, nor Maryland had control of the waters leading to these several localities. The Board of Health of Philadelphia, under these circumstances, appealed to the National Board of Health for defense, and the president, after hearing the facts in the case, asked the board to draw up a plan for establishing a quarantine station at a spot where the United States will have control or may by the law obtain it, and these important cities are thus defended from the hazards to which previously they have been subjected.

Some of the correspondents of the daily papers have alluded to the "uselessness" of the boards; while others name with rebuke its "reckless extravagance." I do not think that such expressions can be justly applied.

The short space of time during which the board has been in operation has prevented anything very striking from being manifested as the result of its work. But I think the following may be predicated of it. By its circulars and by its special agents throughout the Southwest, it has greatly assisted the people there to prepare for the threatened epidemic of yellow fever; it has urged everywhere the duty of cleanliness; where there has been poverty and the epidemic has broken out it has, with the permission of the secretary of the treasury, assisted pecuniarily the sanitary authorities. Various requisitions have been made preparatory to any threatened epidemic. Over one hundred thousand dollars have in this way been hypothetically promised by the treasury department; but only about twenty thousand have been actually spent, and if no epidemic of a general character should attack the Mississippi Valley, not a dollar of this only possibly needed money will be expended.

It has under orders, and now operating chiefly in and around Memphis and the adjacent country, sixteen inspectors uuder pay. It has eight more, in reserve, without pay. The story of Boston inspectorship, at the rate of eighteen dollars a day, as told by a daily paper, is simply a fabrication, originating no one knows how. By the board's means chiefly, Memphis has been surrounded by an impenetrable sanitary belt. No one can enter it save by stealth; no 
one can leave it without a license from the health authorities of the place, and only after six hours of fumigation and disinfection of all of his clothing. A telegram is also sent to the city where he intends to go, and a certificate of the facts in the case given to him to present at any place at which he may stop as a refugee. No railroad car from the surrounding country can come within a radius of eighty miles. Mounted inspectors around the city guard approaches to it both day and night. The result apparently has been that the disease, instead of devastating a large part of the valley, has been pent up within narrow limits. Horrible enough have been its effects in that ill-fated city of Memphis. But when we hear of the filth in many of the houses, and how stolidly indifferent to the propriety of cleansing every homestead the authorities and citizens have been, wholly ignoring in fact the warning lessons of last summer, it seems but a terrible, though not unexpected punishment for the total neglect by all of the divine law of cleanliness. What can we hope of any society which will permit even one family of six or seven persons to cut a hole in the floor in one of the lower rooms of the house and then use the aperture for a watercloset and urinal into the cellar below! A priori, one would have anticipated the fatal result of almost any epidemic under such circumstances. Of course, the board had no control of such cases until after the epidemic burst out, and then it was too late to save the stricken family.

The board has assisted in the establishment of a camp outside of the city, and has urged all who can leave it to depart or to take refuge at the camp. Unfortunately, the ignorant negroes, having little faith in the white man, refuse very generally to leave home. At least thirty thousand persons have quitted Memphis. About ten thousand remain, the great majority of whom are negroes.

But the board has not considered that its chief duty was to Memphis or to any single place however suffering. It looks forward, and would take the place, as far as it can, of instructor of the whole people in sanitary matters. It wishes to prevent disease. It has now a scientific commission at Havana studying yellow fever at its origin. It seeks to gain a sanitary organization for the whole country, and therefore asks for the coöperation of all state and local boards of health. Only by an intimate union between the national and the state sanitary authorities can a really national sanitary organization be effected. The board claims the sympathy of all editors and others capable of influencing to good the public mind. The members ask nothing for themselves. The pay granted by Congress to gentlemen from distant parts of the country to induce them to leave their business and go to Washington is so ridiculously small that nothing but a sense of duty, which ought to animate every citizen of a republic to uphold a public work of beneficence, mingled, doubtless, with a certain not dishonorable pride in the fact of his being selected by the president to carry forward this important measure, could induce any one to consent to become a member of the National Board of Health.

The members therefore feel that they have a right to the sympathy and forbearance of all good men and women, upon the ground of their being engaged in the sacred but herculean task of teaching this nation to cleanse itself and to ward off fatal disease.

Yours very truly.

Henky I. Bownteh. 